\title{
Biological Treatment of Used Engine Oil by Single and Mixed Bacterial Cultures Isolated from Soil of Mechanic Workshops

E-mail: amelali71@yahoo.com

\begin{abstract}
The accumulation of hydrocarbon waste, such as used engine oils in environments, has many impacts on humans and other organisms, therefore many researches were achieved to degrade or remove or consume these pollutants. The aim of the current study is to get a local bacterial isolates has high ability to degrade the spent engine oil as a single or mixed culture. Five soil samples contaminated with spent engine oil were collected from mechanic workshops in Baghdad city to isolate degrading bacteria using Bushnell Hans medium (BHM), pH 7 with 5\% of used engine oil. While the growth patterns and gravimetric analysis was used to reveal the ability of these isolates to degrade spent engine oil in liquid BHM medium. The best three isolates A4, B6 and D5 were identified and the optimal temperature and $\mathrm{pH}$ for biodegradation of spending engine oil were studied. Also, the consortium culture of three isolates was tested their ability to utilize spent engine oil under the same conditions for single isolate. Twenty five bacterial isolates were obtained from contaminated soil samples and three isolates appeared a maximum degradation rate $\mathbf{7 4 . 6 , 7 0 . 2}$ and $\mathbf{7 8 . 5 \%}$ respectively. The results from identification tests were showing these isolates belong to Bacillus sp., Acinetobacter sp. and Pseudomonas sp., respectively. The studied three isolates gave the best degradation when incubated at $30^{\circ} \mathrm{C}$ in BHM medium $\mathrm{pH}$ 7. While other results were indicated that consortium cultures are more effective $\mathbf{9 0 . 2 \%}$ than all experiments that used single isolate.
\end{abstract}

Key words: Biodegradation, Bacterial isolates, spent engine oil.

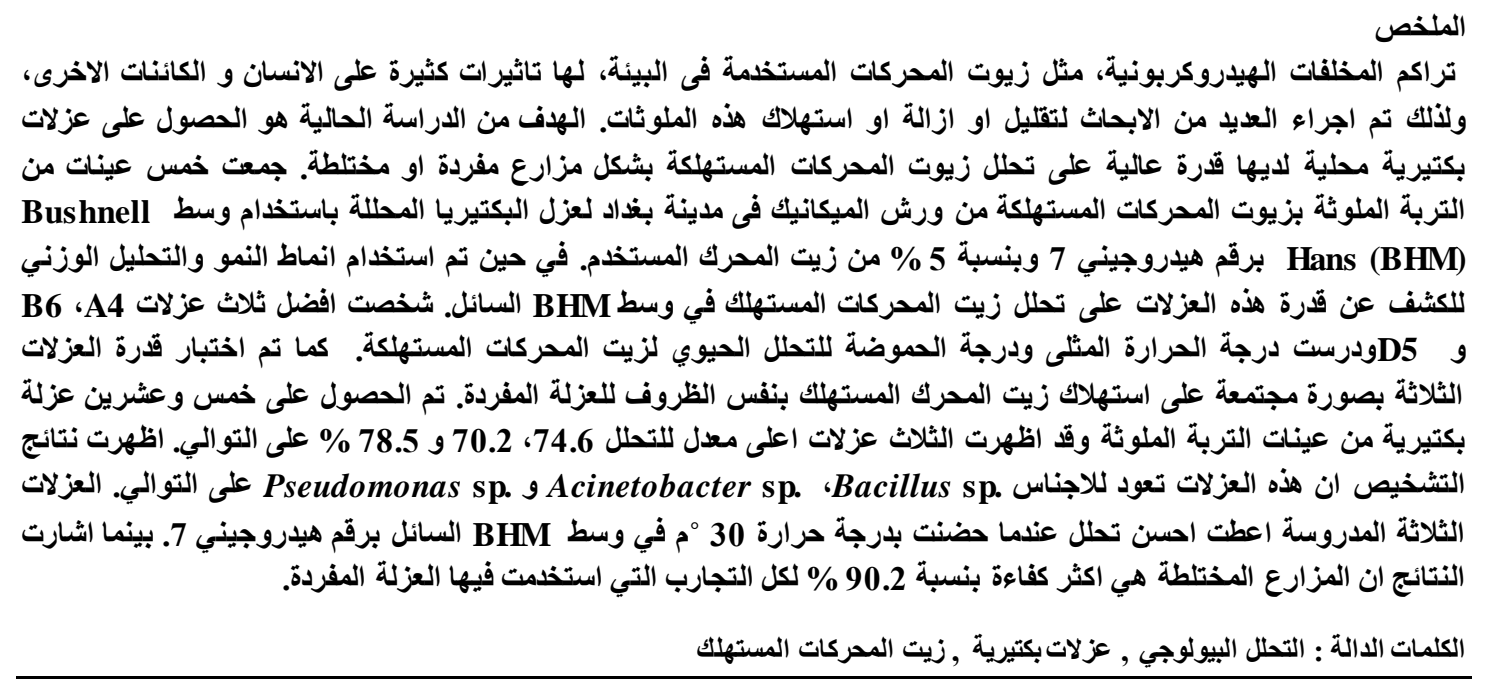

\section{Introduction}

Pollution with hydrocarbon materials and its products such as gasoline, fuel, engine oil, residues of fuel, and spent engine oil, has more attention according to their effects on environment pollution [1]. The most important sources of soil pollution in Baghdad/ Iraq are due to the discharging of spending engine oils from cars and many types of machines used for generating the electricity and other purposes. The main pollutants in spending oils are the polycyclic aromatic hydrocarbons (PAHs) and 
metals, these pollutants can be considered the main cause to occur the mutations and therefore the spread of cancer [3, 4]. A huge amounts of spending oils can be generated at each day from the processes to change the oils of cars and other engines in the mechanical workshops, therefore must be recycled. However, most of them is treated using the processes of incineration or dumping. So, the world need to other methods to recycle these pollutants to prevent their harmful effects on environment [5]. The remediation processes using bacteria and other organisms are depending on the ability of these organisms to degrade or remove or consume the hydrocarbon contaminants as a percentage or completely [6]. Harder (2004)[7], showed that the bioremediation process represents about for 5 to 10 percent from the treatment methods used in for all methods used to treat spent oils or clean up the environment from them. The use of mixed cultures in the processes of degradation to degrade the hydrocarbon wastes was achieved in many researches than those used the pure cultures [8]. Also in ecosystems, there are many microbial communities able to work together to degrade the oil pollutants, according to their ability to consume these pollutants and nature of environmental conditions in sites [9].

The aims of this study were focused on the isolation and screening of bacteria that degrade the spent engine oil and study the effect of temperature and $\mathrm{pH}$ on degradation of used oil, also the effect of single and mixed cultures on degradation was detected.

\section{Materials and Methods}

\section{Collection of contaminated soils}

Soils contaminated with mainly spent engine oil were collected from five different areas of mechanic workshops in Baghdad city during 1-28 April, 2016. These selected sites were polluted with spent engine oil for a long time (more than 10 years). The $25 \mathrm{~g}$ of soil samples was taken by sterilizing spatula from a depth of $0-5 \mathrm{~cm}$ and transferred into a sterilized container [10].

\section{Isolation of Bacteria}

The samples of used engine oil-contaminated soils were used to isolate the bacteria by inoculating $1 \mathrm{~g}$ from them in flasks $50 \mathrm{ml}$ of liquid Bushnell Haas medium (BH medium) supplemented with 5\% spent engine oil as carbon source and then the flasks were incubated in shaker incubator $150 \mathrm{rpm}$ at $30^{\circ} \mathrm{C}$ for 7 days. After incubation period $0.1 \mathrm{ml}$ from each flask was transferred into the plates of solid $\mathrm{BH}$ medium with $5 \%$ spent engine oil and incubated at $30^{\circ} \mathrm{C}$ for $3-5$ days, then the single colonies grown on solid medium were sub-cultured into plates of nutrient agar [11].

\section{Monitoring of bacterial growth}

The bacterial growth in the liquid BH medium was determined according to the optical density of bacterial cultures at $600 \mathrm{~nm}$ using spectrophotometer [11].

\section{Extraction and determination of residual oil}

The residual of used engine oil in liquid $\mathrm{BH}$ medium was measured by gravimetric method, the $\mathrm{BH}$ medium of bacterial cultures $50 \mathrm{ml}$ after incubation period was transferred into separating funnels and treated with dichloromethane $50 \mathrm{ml}$, and then the organic solvent layer was collected and filtered through $15 \mathrm{~g}$ of sodium sulfate. The percentage of spending engine oil biodegradation was calculated according to following equation [10].

$$
\% \text { biodegradation of used oil }=\frac{\text { weight of oil in control }- \text { weight of oil in test }}{\text { weight of oil in control }} \times 100
$$

\section{Screening of bacterial isolates}

$250 \mathrm{ml}$ flasks of the sterilized liquid $\mathrm{BH}$ medium of $\mathrm{pH} 7$ supplemented with $5 \%$ spent engine oil were used to screen the bacterial isolates for their efficiency to degrade used engine oil. The flasks were inoculated with isolates (one flask was left uninoculated as a positive control), then all flasks were incubated in shaker incubator $150 \mathrm{rpm}$ for 10 days at $30^{\circ} \mathrm{C}$. After incubation period growth of bacteria at $600 \mathrm{~nm}$ and residual of used engine oil in liquid medium were determined [12].

\section{Identification of selected isolates}

The most active bacterial isolates have been selected depending on their ability to consume the used engine oil in liquid medium, then these isolates were characterized to genus level based on colon y morphology, Gram staining, and biochemical tests (such as lactose fermentation, citrate, catalase, indole, methyl red, oxidase and etc.) according to the Bergey's Manual[13]. 


\section{Effect of temperature and $\mathrm{pH}$ on degradation}

The sterilized liquid BH medium supplemented with $5 \%$ spent engine oil was used to determine the effect of temperatures and $\mathrm{pH}$ values on degradation of used engine oil.

The flasks of $\mathrm{BH}$ medium of $\mathrm{pH} 7$ were inoculated by selecting isolates and incubated at different temperatures $\left(20,25,30,35\right.$ and $\left.40^{\circ} \mathrm{C}\right)$ for 10 days, while the effect of $\mathrm{pH}$ was studied by preparing $\mathrm{BH}$ medium with different $\mathrm{pH}$ values $(5,6,7,8$ and 9) and then were inoculated by selecting isolates and incubated in $30^{\circ} \mathrm{C}$ for 10 days. After the incubation period the bacterial growth and residual oil were determined [14].

\section{Biodegradation by single and consortium culture}

The consortium culture of Bacillus sp., Acinetobacter sp. and Pseudomonas sp. was prepared by mixing equal volumes of pure bacterial cultures together, then the liquid $\mathrm{BH}$ medium, $\mathrm{pH} 7$ with $5 \%$ spent engine oil was inoculated by single and consortium culture of selected isolates. The flasks were incubated in shaker incubator $150 \mathrm{rpm}$ at $30^{\circ} \mathrm{C}$ for 10 days, and then the bacterial growth and biodegradation of used engine oil were determined [15].

\section{Results and discussions}

\section{Bacteria isolated from samples}

Twenty five bacterial isolates were obtained from the five soil samples collected from mechanic workshops using the solid $\mathrm{BH}$ medium, $\mathrm{pH} 7$ supplemented with 5\% spent engine oil as carbon source. The results of isolation processes as in Table (1) show a clear difference in the number of isolates obtained from each soil sample, this may be due to the nature of soil samples according to the quantity of contaminants in it and the length of pollution period.

Table (1): Isolation the bacteria from samples of spent engine oil-contaminated soils collected from different regions of Baghdad city, using $\mathrm{BH}$ medium with $5 \%$ used engine oil as substrate.

\begin{tabular}{|c|c|c|c|}
\hline Soil samples & Symbol & Collection period & $\begin{array}{l}\text { Number of } \\
\text { isolates }\end{array}$ \\
\hline Al-Jadriya & $\mathbf{A}$ & $1^{\mathrm{th}}$ April, 2016 & 5 \\
\hline Al-Karrada & $\mathbf{K}$ & $7^{\text {th }}$ April, 2016 & 2 \\
\hline Al-Bayaa & B & $14^{\text {th }}$ April,2016 & 9 \\
\hline Al-Ghazaliyah & G & $21^{\text {th }}$ April,2016 & 2 \\
\hline \multirow[t]{2}{*}{ Al-Dora } & D & $28^{\text {th }}$ April,2016 & 7 \\
\hline & & $\begin{array}{l}\text { Total isol } \\
\end{array}$ & 25 \\
\hline
\end{tabular}

The current work corroborated the exist data on the indigenous bacteria that can utilize or metabolize hydrocarbons in any polluted site. Oil contaminated soil is the best source for the isolation of oil degrading bacteria and may be used for the isolation of other microorganisms. The isolated bacteria can be used for the degradation of different hydrocarbon containing oil and it can also be used for the remediation of contaminated sites.

\section{Screening of bacteria}

The twenty five bacterial isolates were investigated for their ability to utilize the used engine oil in liquid $\mathrm{BH}$ medium. The bacterial growth and biodegradation of used engine oil for inoculat ing isolates were measured as optical density at $600 \mathrm{~nm}$ and by gravimetric method.

The results in Table (2) exhibited that the isolates have different capability to consume the substrate and the isolates A4, B6 and D5 appeared the highest growth rate 0.67, 0.61 and 0.73 respectively, compared with other isolates in this study. 
Table (2): Primary screening of bacterial isolates in liquid BH medium, pH 7 with $5 \%$ spent engine oil, flasks incubated for 10 days at $30^{\circ} \mathrm{C}$.

\begin{tabular}{cccccc}
\hline Isolates & $\begin{array}{c}\text { Bacterial } \\
\text { growth at } \\
\text { 600 nm }\end{array}$ & Isolates & $\begin{array}{c}\text { Bacterial } \\
\text { growth at } \\
\text { 600 nm }\end{array}$ & $\begin{array}{c}\text { Isolates } \\
\text { Bacterial }\end{array}$ & $\begin{array}{c}\text { growth at 600 } \\
\text { nm }\end{array}$ \\
\hline A1 & $\mathbf{0 . 2 9}$ & B3 & $\mathbf{0 . 3 3}$ & D1 & 0.44 \\
A2 & $\mathbf{0 . 4 4}$ & B4 & $\mathbf{0 . 2 6}$ & D2 & 0.39 \\
A3 & $\mathbf{0 . 1 1}$ & B5 & $\mathbf{0 . 5 0}$ & D3 & 0.41 \\
A4 & $\mathbf{0 . 6 7}$ & B6 & $\mathbf{0 . 6 1}$ & D4 & $\mathbf{0 . 2 6}$ \\
A5 & $\mathbf{0 . 0 9}$ & B7 & $\mathbf{0 . 4 6}$ & D5 & $\mathbf{0 . 7 3}$ \\
K1 & $\mathbf{0 . 0 9}$ & B8 & $\mathbf{0 . 1 7}$ & D6 & $\mathbf{0 . 5 2}$ \\
K2 & $\mathbf{0 . 1 6}$ & B9 & $\mathbf{0 . 3 1}$ & D7 & $\mathbf{0 . 2 2}$ \\
B1 & $\mathbf{0 . 2 4}$ & G1 & $\mathbf{0 . 2 8}$ & & \\
B2 & $\mathbf{0 . 4 2}$ & G2 & $\mathbf{0 . 0 8}$ & & \\
\hline
\end{tabular}

However, the experiment of degradation for spent engine oil showed also a high variation between the isolates about their ability to degrade the spent oil as in Table (3), the results also proved that the isolates A4, B6 and D5 are more efficient isolates to degrade the spent oil $74.6 \%, 70.2 \%$ and $78.5 \%$ respectively, compared with other isolates.

Table (3): Secondary screening of bacterial isolates in liquid $\mathrm{BH}$ medium, pH 7 with $5 \%$ spent engine oil, flasks incubated for 10 days at $30^{\circ} \mathrm{C}$.

\begin{tabular}{cccccc}
\hline Isolates & $\begin{array}{c}\text { Biodegradation } \\
(\%)\end{array}$ & Isolates & $\begin{array}{c}\text { Biodegradation } \\
(\%)\end{array}$ & Isolates & $\begin{array}{c}\text { Biodegradation } \\
(\%)\end{array}$ \\
\hline A1 & $\mathbf{4 5 . 3}$ & B3 & $\mathbf{5 5 . 9}$ & D1 & $\mathbf{6 3 . 1}$ \\
A2 & $\mathbf{6 2 . 6}$ & B4 & $\mathbf{5 3 . 3}$ & D2 & $\mathbf{5 8 . 5}$ \\
A3 & $\mathbf{3 9 . 4}$ & B5 & $\mathbf{6 7 . 3}$ & D3 & $\mathbf{5 9 . 4}$ \\
A4 & $\mathbf{7 4 . 6}$ & B6 & $\mathbf{7 0 . 2}$ & D4 & $\mathbf{4 9 . 9}$ \\
A5 & $\mathbf{3 2 . 9}$ & B7 & $\mathbf{6 3 . 8}$ & D5 & $\mathbf{7 8 . 5}$ \\
K1 & 29.4 & B8 & $\mathbf{4 7 . 8}$ & D6 & $\mathbf{6 9 . 2}$ \\
K2 & 41.2 & B9 & $\mathbf{5 4 . 6}$ & D7 & $\mathbf{5 1 . 2}$ \\
B1 & $\mathbf{5 0 . 1}$ & G1 & $\mathbf{5 2 . 3}$ & & \\
B2 & $\mathbf{6 0 . 7}$ & G2 & $\mathbf{2 6 . 5}$ & & \\
\hline
\end{tabular}

These results indicate that this bacterial isolate utilized engine oil as a sole source of carbon and energy. Enriched culture of five soil samples was spread into the $\mathrm{BH}$ agar plates which are the selective media for oil degrading bacteria.

Identification of bacteria

The most active bacterial isolates A4, B6 and D5 for degradation of used engine oil were identified according to morphological and biochemical tests. The results in Table (4) indicate that the isolates A4, B6 and D5 belong to Bacillus sp., Acinetobacter sp., and Pseudomonas sp., respectively. 
Table (4): Morphological and biochemical tests to identify the isolates.

\begin{tabular}{|c|c|c|c|}
\hline Tests & $\overline{\mathrm{A4}}$ & $\overline{\text { B6 }}$ & $\overline{\text { D5 }}$ \\
\hline Form & Circular & Round & Circular \\
\hline Surface & Smooth & Smooth & Smooth \\
\hline Color & Cream & Cream & Whitish \\
\hline Margin & Undulate & Entire & Entire \\
\hline Elevation & Raised & Slightly raised & Convex \\
\hline Opacity & Opaque & Opaque & Translucent \\
\hline Gram stain & Positive & negative & negative \\
\hline Catalaes & + & + & + \\
\hline Oxidase & + & - & + \\
\hline Citrate utilization & + & + & + \\
\hline Lactose ferment. & - & - & - \\
\hline $\mathrm{H}_{2} \mathrm{~S}$ production & + & - & - \\
\hline Methyl red & - & - & - \\
\hline Nitrate reduction & + & - & + \\
\hline Indol & - & - & - \\
\hline Urease & - & - & - \\
\hline Motility & + & - & + \\
\hline
\end{tabular}

Such results are similar to those obtained by [16] who revealed that the Pseudomonas, Bacillus, Proteus, Salmonella and Streptococcus were isolated from oil contaminated soil samples, two of these bacteria (Pseudomonas and Bacillus) have been reported to be among the most frequently isolated bacteria from hydrocarbon-polluted sites [17,18]. Thenmozhi et. al., (2011) [11] have isolated three bacterial isolates which are able to consume spent oil as substrate. The isolate Pseudomonas aeruginosa was given the best result for oil degradation $81 \%$ after 30 days of incubation, while the Serratia marcescens and Bacillus licheniformis gave $72 \%$ and $60 \%$ respectively under the same conditions.

The results of this study have proven Pseudomonas species are the most common bacterial hydrocarbon degraders which is agreed with that reported in the literature [19-20]. Acinetobacter spp. is widespread in nature and can remove or degrade a wide range of organic compounds [21] and inorganic compounds [22].

Effect of temperature and $\mathrm{pH}$ on degradation

The optimal temperature to degrade used engine oil by Bacillus sp., Acinetobacter sp. and Pseudomonas $s p$. were studied in liquid BH medium supplemented with 5\% substrate as carbon source. The results of the growth rate and biodegradation are demonstrated in Figures $(1,2)$ respectively, which show that the best growth and degradation rate were obtained at $30^{\circ} \mathrm{C}$ compared with other studied temperatures. Also the results revealed that the Pseudomonas sp. has given the highest ability to degrade spent engine oil 78.9\%, while other isolates Bacillus sp. and Acinetobacter sp. have given $74.7 \%$ and $70.4 \%$ respectively. 


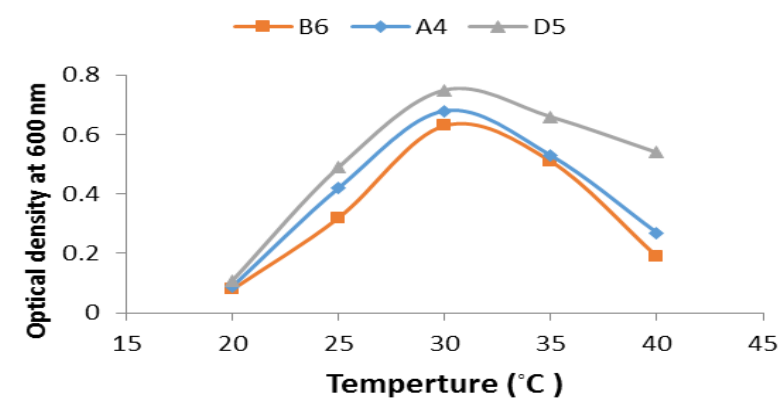

Fig. (1): Effect of temperature on bacterial growth of three isolates in liquid BH medium with $5 \%$ used engine oil, pH 7 after 10 days of incubation.

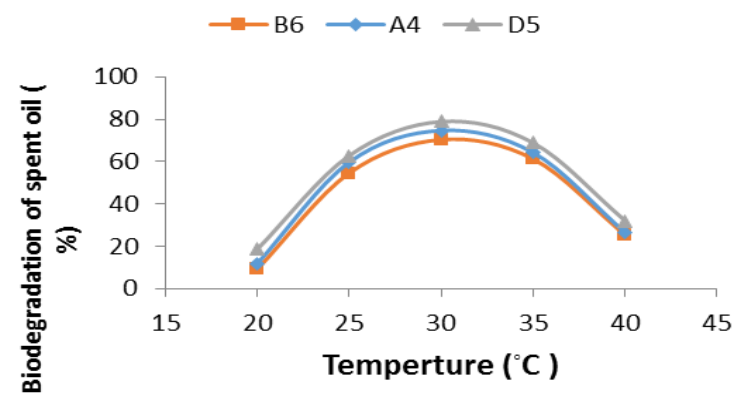

Fig. (2): Effect of temperature on degradation rate of used engine oil by three isolates in liquid BH medium, pH 7 after 10 days of incubation.

The effect of $\mathrm{pH}$ on using engine oil degradation by Bacillus sp., Acinetobacter sp. and Pseudomonas $s p$. were investigated using liquid $\mathrm{BH}$ medium with $5 \%$ spent oil as substrate. Figures $(3,4)$ show different ability to grow and degrade the spent oil by three isolates with different $\mathrm{pH}$ values. The maximum growth and degradation has been obtained at $\mathrm{pH} 7$ by three isolates, while the Pseudomonas $s p$. has appeared maximum degradation $(79.1 \%)$ for spending engine oil compared with other isolates Bacillus sp. and Acinetobacter sp. which has given $74.8 \%$ and $70.5 \%$ respectively.

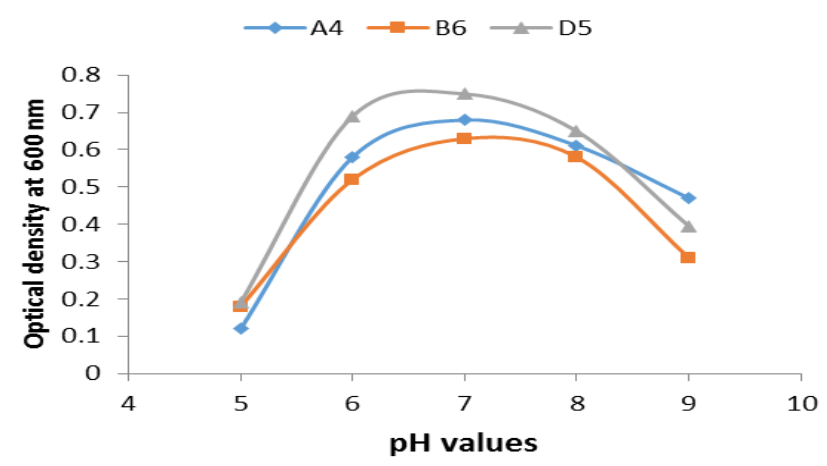

Fig. (3): Effect of pH values on bacterial growth of three isolates in liquid $\mathrm{BH}$ medium, pH 7 with $5 \%$ used engine oil after 10 days of incubation. 


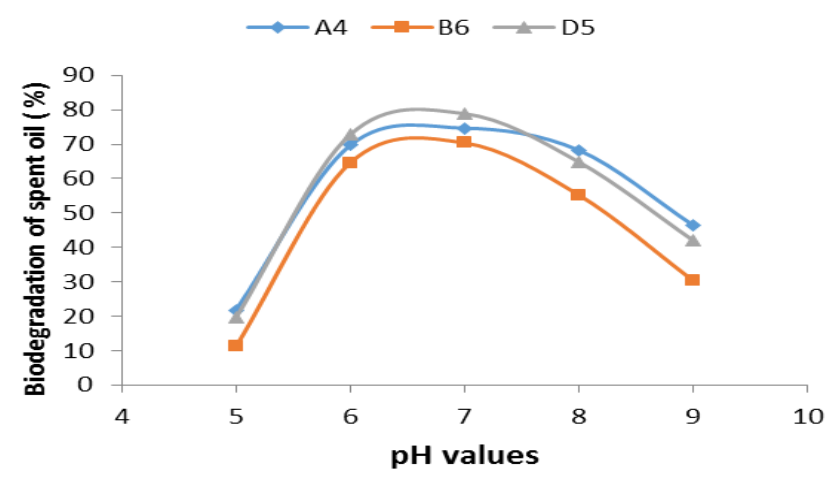

Fig. (4): Effect of pH values on degradation rate of used engine oil by three isolates in liquid BH medium after 10 days of incubation.

These results, at a temperature of $30^{\circ} \mathrm{C}$, is in good agreement with that reported by [23] who found that the temperature between $30-37^{\circ} \mathrm{C}$ showed the maximum degradation for spent engine oil by a microbial consortium at neutral or slightly alkaline $\mathrm{pH}$ of the medium.

\section{Biodegradation by single mixed culture}

The ability of single and a consortium culture of Bacillus sp., Acinetobacter sp. and Pseudomonas sp. were tested in order to determine their ability to grow and consume the spent engine oil using $\mathrm{BH}$ medium with 5\% substrate, after 10 days of incubation the bacterial growth and remaining spent oil in flasks will be calculated.

According to the results from a Table (5) the consortium culture has appeared the highest ability 0.94 and $90.2 \%$ as bacterial growth and oil degradation respectively, compared with single isolate of Bacillus sp., Acinetobacter sp. and Pseudomonas sp.

Table (5): Effect of single and consortium culture on bacterial growth and biodegradation of used engine oil in liquid BH medium after 10 days.

\begin{tabular}{ccc}
\hline Type of inoculum & $\begin{array}{c}\text { Bacterial growth } \\
\text { at } 600 \mathrm{~nm}\end{array}$ & $\begin{array}{c}\text { Percentage of } \\
\text { biodegradation \% }\end{array}$ \\
\hline Bacillus $s p$. & $\mathbf{0 . 6 8}$ & 74.8 \\
Acinetobacter $s p$. & $\mathbf{0 . 6 3}$ & $\mathbf{7 0 . 5}$ \\
Pseudomonas $s p$. & $\mathbf{0 . 7 5}$ & 79.1 \\
Consortium culture & $\mathbf{0 . 9 4}$ & $\mathbf{9 0 . 2}$ \\
\hline
\end{tabular}

This is in accordance with other reports [24,25] who have revealed that the biodegradation of the used engine oil by mixed cultures was more effective, because some species in mixed culture can be consume the intermediates compounds released from degradation processes of oil, their products and hydrocarbon wastes, while other species in the mixed culture can be lead to utilize all these pollutants and their byproducts ${ }^{[31 ; 32]}$. The most important reduction is related to the nature of species in the consortium culture that can consume $90 \%$ of aliphatic compounds during 30 days under same environmental conditions.

The best reduction of hydrocarbons was seen when used the Pseudomonas aeruginosa [11]. The pure culture of Pseudomonas aeruginosa was appeared the maximu m ability to degrade $53.44 \%$ of engine oil within 30 days, while Bacillus sp.gave $34.92 \%$ value for engine oil degradation under the same conditions [25].

The single organisms often prefer to use when the process done on one hydrocarbon substrate [26]. However, a mixed culture of different bacterial species is usually used to produce all enzymes necessary for complete degradation of complex mixtures of hydrocarbons [27]. 


\section{References}

1. Su, WT., Wu, BS., and Chen, WJ. (2011). Characterization and biodegradation of motor oil by indigenous Pseudomonas aeruginosa and optimizing medium constituents. J. Taiwan Inst. Chem. Eng. 42: 689-695.

2. Mandri, T. and Lin, J. (2007). Isolation and characterization of engine oil degrading indigenous microorganisms in Kwazulu-Natal South Africa. African. J. Biotechnol. 6(1): 023-027.

3. Boonchan, S., Britz, M.L., and Stanley, G.A. (2000). Degradation and mineralization of highmolecular-weight polycyclic aromatic hydrocarbons by defined fungal-bacterial cocultures. Applied Environ Microbiol. 66(3):1007-19.

4. Kalyani, K.A. and Pandey, K.K. (2014).Waste to energy status in India: A short review. Renew Sustain Energy Rev. 31:113-120.

5. Go'mez, M.J., Pazos, F., Guijarro, F.J., de Lorenzo, V. and Valencia, A. (2007). The environmental fate of organic pollutants through the global microbial metabolism. Molecular. Syst. Biol. 3: 1-11.

6. Harder, E. (2004). Bioremediation of engine oil. Little Flower Academy, Dallas, Texas.

7. Trindade, L.G., Sobral, A.C.L., Rizzo, S.G.F., Leite, P.V.O., and Soriano,A.U.(2005). Bioremediation of a weathered and a recently oil-contaminated soils from Brazil: A comparis on study. Chemosphere, 58: 515-522.

8. Kim, B.H., Park, H.S., Kim, H.J., Kim, G.T., Chang, I.S., Lee, J. and Phung, N.T. (2004). Enrichment of microbial community generating electricity using a fuel-cell-type electrochemical cell. Applied Microbiol. Biotechnol 63: 672-681.

9. Adams, D., Bawa, D., Abdullahi, Y., Wuyep, P. and Abba, D. (2016). Molecular characterization and determination of bioremediation potentials of some bacteria isolated from spent oil contaminated soil mechanic workshops in Kaduna metropolis. World Appl. Sci. J. 34 (6): 750-759.

10.Thenmozhi, R., Nagasathya, A. and Thajuddin, N. (2011). Studies on biodegradation of used engine oil by consortium cultures. Advances in Environm Biol., 5(6): 1051-1057.

11.Kaur, H., Kaur, S. and Bansal, J. (2014). Comparis on of biodegradation potential of Bacillus sp. and Pseudomonas sp. isolated from oil contaminated soil. International J. Biology, Pharmacy and Allied Science, 3(9): 2119-2130.

12.Holt, J.G., Krieg, N.R., Sneath, P.H., Staley, J.T. and Williams, S.T. (1994). Bergeys Manual of Determinative. Bacterioogy.9thed. Baltimore.MD: Williams and Wilkins.

13.Shahida, A. A., Sadiya, S., Shehu, A. and Salau, I. A. (2015). Biodegradation of spent engine oil by bacteria isolated from oil contaminated soil in mechanic workshop of Sokoto metropolis, Nigeria. Asian J. Sci. Tech., 6(10): 993-999.

14.Ghazali, F. M., Rahman, R., Salleh, A. and Basri, M. (2004) Biodegradation of hydrocarbons in soil by microbial consortium. International Biodet. \& Biodeg. 54: 61 - 67.

15.Adegbola, GM., Eniola, KIT. and Opasola, OA. (2014). Isolation and identification of indigenous hydrocarbon tolerant bacteria from soil contaminated with used engine oil in Ogbomoso, Nigeria. Advances Appl. Sci. Res., 5(3): 420-422.

16.Atlas, RM. (1992). Petroleum microbiology. Academic Press. Baltimore: 363-369.

17.Okoh, A.I., and Trejo-Hernandez, M.R. (2006). Remediation of petroleum hydrocarbon polluted systems: exploiting the bioremediation strategies. African J. Biotechnol., 5(25): 2520-2525

18.Johnson, H.A., Pelletier, D.A., and Spormann, A.M. (1996). Isolation, characterization of anaerobic ethylbenzene dehydrogenase novel mofes enzyme. Journal Bacteriol 183(15): 4536-4542.

19. Pokethitiyook, P., Sungpetch, A., Upathame, S., and Kruatrachue, M. (2003). Enhancement of Acinetobacter calcoaceticus in biodegradation of Tapis crude oil. Applied. Environ. Microbiol. 42: 110.

20. Abdel-El-HD, Moawad H., Zaki, E., and Zaki, S. (2002). Molecular characterization of phenoldegrading bacteria isolated from different Egyptian ecosystems. Microbiology Ecol. 43(2): 217-224.

21. Boswell, C.D., Dick, R.E., Essles, H. and Macaskie, L.E. (2001). Phosphate uptake and release by Acinetobacter johnsonli in continuous culture and coupling of phosphate release to heavy metal accumulation. Journal of Ind Microbiol Biotechnol. 26(6): 333-340.

22. Aleer, S., Adetutu ,E.M., Makadia, T.H., Patil, S., and Ball, A.S. (2011). Harnessing the hydrocarbondegrading potential of contaminated soils for the bioremediation of waste engine oil. Water Air Soil Pollut. 218:121-130.

23. Bagherzadeh-Namazi, A., Shojaosadati, S.A. and Hashemi-Najafabadi, S. (2008). Biodegradation of used engine oil using mixed and isolated cultures. International J. Environ. Res., 2(4): 431-440.

24.Umanu, G., Akpe, A.R., and Omoikhudu, A. (2013). Oil degradation assessment of bacteria isolated from used motor oil contaminated soils in Ota, Nigeria. RIJABR. 3(4):506-513.

25.Atlas, R. M. (1981). Microbial degradation of petroleum hydrocarbons: An environmental perspective. Microbiology. Rev. 45, 180-209. 
26. Marin M.A., Pedregosa A., Rios S. and Laborda F. (1996).Study of factors influencing the degradation of heating oil by Acinetobacter calcoaceticus MM5. International Biodeterior. Biodegrad., 38: 67-75.

27. Leahy J.G. and Colwell R.R. (1990). Microbial degradation of hydrocarbons in the environment. Microbiology. Rev.54 (3): 305-315. 